\title{
Implementation of a Program of Voluntary Body Donation for Anatomical Study in the University of São Paulo, Brazil
}

\author{
Implementación de un Programa de Donación Voluntaria de Cuerpos \\ para el Estudio Anatómico en la Universidad de São Paulo, Brasil
}

\author{
Thelma Renata Parada Simão*; Maria Angélica Miglino**; Jodonai Barbosa da Silva***; \\ Concepta McManus ${ }^{* * * * *}$ \& Edson Aparecido Liberti*******
}

SIMÃO, T. R. P.; MIGLINO, M. A.; DA SILVA, J. B.; McMANUS, C. \& LIBERTI E. A. Implementation of a program of voluntary body donation for anatomical study in the University of São Paulo, Brazil. Int J. Morphol., 34(4):1494-1501, 2016.

SUMMARY: Unclaimed corpses were for many years the supply of human material for the study of human anatomy. However, due to improved quality of life and technology, there has been the surround these. Faced with these circumstances, and the impossibility of total replacement of this material by others in training future professionals and the endless dissection technique, the Donation Voluntary Bodies for Anatomical Study is presented as an alternative to capture corpses or who wish to donate your body or part of it to research institutions and scientific study, without obtaining any pecuniary gain. Thus, the present study aimed to gather information about the knowledge and belief of the population of anatomists and freshmen, on the subject; obtain information on the importance of discipline and dissection for professional practice and reliability of the general population, and develop Donation Program Voluntary Bodies for Anatomical Study (pdvcea) for University of São Paulo (DA-ICB/USP). Regarding the importance of dissection for vocational training is considered, for the general population, such as reliability factor in professional medical surgeon, the possibility of donating Bodies is not unknown to the majority of the population studied, which do not necessarily set in potential donors. The pdvcea is created, institutionalized, but still in the process of acquiring gravesite tributes to the institution; dependent for its dissemination, clarification and placement in mass media, to decrease the time of drafting the seat of death, without financial loss to the relatives of the donors.

KEY WORDS: Donation. Corpses. Dissection. Anatomy.

\section{INTRODUCTION}

The use of human cadavers for the study of human anatomy, used since primordial times (De Caro et al., 2009), is widely discussed in Brazil. This is due to the reduction in the availability of indigents, and bureaucracy with high costs associated with unclaimed corpses, which means the offer of this invaluable didactic material, has been drastically reduced (Pasqualucci, 2012). This lack of natural material has led to the rise in the use of alternative methods such as computerized imaging and anatomical models to try to solve the problem, at least in part. The use of models made from different synthetic materials, even though they maintain close similarity to the natural material, have been unable to totally substitute the latter, mainly through difficulties in faithfully representing internal structures of some systems (Carvalho et al., 2010).
Due to the administrative problems encountered when dealing with unclaimed corpses and the impossibility of complete substitution by alternative methods (Pasqualucci, 2012; Gunderman, 2008; Cornwall \& Stinger, 2009), Universities in several countries have implemented programs of voluntary body donation, which vary depending on specific laws in the regions of use.

Programs of voluntary body donations for anatomy studies are not recent. In Brazil, from a total of 2377 higher education institutions, only nine have a program of voluntary body donation and only two (Universidade Federal de Ciêncas da Saúde de Porto Alegre and Universidade Federal de Minas Gerais) have an official program (Rocha et al., 2010; UFMG, 2010). In São Paulo State, there are 36

\footnotetext{
Full Professor, Department of Anatomy of the University Paulista (UNIP); SP, Brazil.

** Full Professor, Department of Surgery, Faculty of Veterinary Medicine, University of São Paulo; SP, Brazil.

**** Assistant Professor, Federal University of Piauí, PI, Brazil.

***** Full Professor, University Federal of Rio Grande of Sul; RS, Brazil.

${ }^{* * * * * *}$ Full Professor, Department of Anatomy, Biomedical Sciences Institute, University of São Paulo, SP. Brazil.
} 
medical schools, more than in Minas Gerais (28) and Rio Grande do Sul (11) and almost seven times that in Northeastern States (with 7 courses each in Bahia, Ceará and Pernumbuco).

The aim of the present study was to develop, legalize and establish a program for voluntary donation of bodies for anatomical study in The University of São Paulo (VDBAnat/USP) and latter extension to all universities in São Paulo state.

\section{MATERIAL AND METHOD}

Understanding and evaluating the problem. Several sources of information on voluntary donation of bodies for anatomical study were investigated:

i) Laws, provisions and rules on the destination of bodies for human anatomy in São Paulo State. The procedures for receiving bodies for study in the schools of medicine in São Paulo State were examined including federal law 8501/92 and provision 16/97 of the Internal Affairs of Justice for the State of São Paulo. The internal rules of the Department of Anatomy of the Institute of Biomedical sciences of the University of São Paulo (DA-ICB/USP) were also studied as this department uses cadavers from unclaimed indigents from the capital city's coroner service (SVOC).

ii) Information available from Funeral Agencies of São Paulo Municipality (SFMSP) on the procedures needed for voluntary donation of bodies for anatomical study. All 13 SFMSP agencies were contacted. The person responsible for the agency was informed of the death of an individual who, in life, had made their body available for anatomical studies at the Faculty of Medicine. They were also informed that the following documents were available from their legal representatives: death certificate, declaration of intention to donate written while alive, signed and notarized in the presence of three witnesses) and the university documents signed by the legal representative declaring that the university was able to receive the cadaver. Questions asked included - should death be registered, if a wake was necessary, how the body could be transported and what costs were involved.

The VBDAnat/USP Program. For its implementation the following three questionnaires were used:

i) For surgeons (GS) and another for the general public (GP) to evaluate the importance of the anatomy course as well as the practice of dissection for the medical profession. One thousand surgeons (GS) registered on the site (www.cremesp.org.br) of the São Paulo Regional Medical Council were contacted by telephone and then post. All who replied signed an informed consent form approved by the human ethics committee of the University of São Paulo (USP). All replies were anonymous and only complete replies were evaluated. The questionnaire, with official letterhead of USP, had 14 questions including socio-demographic information (age, sex, specialization, religion), opinion on the increasing substitution of cadavers by animals, synthetic material and computerized technologies in universities in Brazil. Three questions were made available on the site www.surveymonkey.com for the GP questionnaire.

ii) For donors (d) and non-donors (nd) from different backgrounds to elucidate their knowledge and beliefs about the Voluntary Bodies Donation Program (VBDP). One thousand questionnaires with three questions were distributed using the site www.surveymonkey.com, open for 30 days. Questions were formed from doubts and explanations about the topic in question given by the authors to diverse public. This questionnaire had 12 questions including socio-demographic (age, sex, profession, religion and level of instruction), as well as knowledge and attitude on the theme, and the motivation for a person to donate or not, their own body for anatomical study. Two groups were formed: i) 423 Anatomists (GA) present at the XXIV Brazilian Anatomy Congress in São Paulo (9 to 13 October 2010) including undergraduate and postgraduate students as well as professionals working in the area; ii) 630 freshmen from the undergraduate courses that have human anatomy as a basic course in their curriculum (Medicine, Odontology, Physio-, Occupational-and speech-therapy, Physical education and nutrition). The questionnaire was given in a single page, without personal identification or any explanation and collected after five minutes. Only complete questionnaires were considered valid.

Responses from the different groups were tested using the chi-square test (Zar, 1984).

\section{RESULTS}

i) Laws, provisions and rules on the destination of bodies for human anatomy in the State of São Paulo. The DA-ICB/ USP elaborated a protocol of documents necessary to obey the federal law 8501/92 on the use of cadavers for studies and scientific research, that only deals with non-claimed bodies (indigents) while provision 16/97 added sub items and regulates the emission of death certificates for these cadavers. 
Of the 13 agencies, nine replied to the contact. When questioned about the procedures necessary for voluntary donation, all were unsure. The replies were as follows:

a) One agency informed that this was a simple procedure compared to routine cases of burial and cremation, with transport carried out by SFMSP.

b) Four agencies informed that all that was necessary was to appear at the agency with the death certificate and the donation document at the SFMSP. Nevertheless, these requested that the central agency be contacted to confirm this information.

c) One replied that they had never carried out this procedure but believed that it was similar to other routine procedures.

d) One said that this was the procedure that had to be carried out by the university/faculty interested in the donation;

e) Two agencies informed that a relative or legal representative along with the receiving institution should go to the SFMSP with the death certificate and donor declarations.

When questioned how the death certificate was obtained in this case, four replied that the procedure was the same as in routine cases, emitted by the SFMSP who would send the certificate to the register, and this document would be available after 5 days. One alerted that it would be necessary to go to the register office before the funeral service. The other four did not have information on the procedure necessary. All nine agencies informed that the funeral service could occur before sending the body to the University, and costs would vary depending on the type of service chosen (flowers, casket, candles, etc).

\section{The VBDAnat/USP Program}

i) Questionnaires for surgeons (GS) and another for the general public (GP) to evaluate the importance of the anatomy course as well as the practice of dissection for the medical profession. Of the 1000 questionnaires sent out, 163 were returned $(16.3 \%)$. Of these, $18.6 \%$ were males and $18.4 \%$ females, with different surgical $(65.6 \%)$ and clinical $(34.4$ $\%$ ) specialities. The mean age was $51.1 \pm 10.7$ years (varying from 30 to 85). Most doctors interviewed consider that knowledge of anatomy is basic to exercise their profession (Table I) and that dissection is important to acquire anatomical knowledge. Dissection was a common practice during their undergraduate course but not post-graduate.
About $2 / 3$ of the doctors trained their skills on humans and animals while $56.2 \%$ used synthetic materials. Most believed that it is not possible to substitute human material with animals, computer images or synthetic material. Numbers in the same line followed by different lower case letters or the same column within a question followed by upper case letters are significantly different by the chi-square test $(\mathrm{P}<0.05)$. Whether or not the doctor had studied anatomy in their undergraduate course was fundamental on forming their opinion on all other training matters $(\mathrm{P}<0.05)$. Those that had not studied anatomy considered their training insufficient (odds ratio (OR) of 10.75) and considered it fundamental for their formation as a doctor (OR 2.51) compared to those that had studied this subject. Surgeons were more likely to consider their training inadequate compared to those working in clinics (OR 1.75) and saw it as fundamental to their profession (OR 4.09). Training during postgrad was important for those having a positive opinion on training with cadavers (OR6.45) with clinics considering it less important (OR 5.43). The substitution of cadavers by other materials (OR 2.67) and animals (OR 1.74) was less well accepted by those with postgraduate training. Those doctors that had training many hours of training in undergrad and postgrad courses considered this fundamental for their profession. Those that considered their training insufficient did not have training on cadavers and few hours at undergraduate and postgraduate level. Religion had an effect on whether the person was willing to donate or not $(\mathrm{P}<0.05)$ with Catholics, atheists and other regions more willing to donate than evangelists, protestant and spiritualists. The patterns for a no donation of the body in anatomists is clearer than for donation. Those that would not donate tend to be single, protestant or atheist, and have no information on how to go about donating their body. The reasons for not donating have to do with family and the desire for a burial.

ii) Questionnaire for the general public using website. The general publics (GP) confidence in the surgeon was answered by 845 people (Table II). For most people who answered the questions their confidence in the surgeon's ability is closely related to him/her studying anatomy with human cadavers. The socio-demographic results for the anatomists (GA) and freshmen are in Table II. Numbers in the same line followed by different lower case letters or the same column within a question followed by upper case letters are significantly different by the chi-square test $(\mathrm{P}<0.05)$. There was no significant differences between groups interviewed (anatomists or freshmen) for sex. In both groups most interviewees were below 30 years of age, single and catholic. Their opinions on voluntary body donation are in Table III. Numbers in the same line followed by different lower case letters or the same column within a question followed by 
Table I: Socio-demographic characterisation of interviewees on their knowledge of voluntary body donation. (Numbers in the same line followed by different lower case letters or the same column within a question followed by upper case letters are significantly different $\mathrm{P}<0.05$ ).

\begin{tabular}{lcc}
\hline & Anatomist & Freshman \\
\hline Sex & $49.3^{\mathrm{Aa}}$ & $57.0^{\mathrm{Aa}}$ \\
Male & $50.7^{\mathrm{Aa}}$ & $43.0^{\mathrm{Aa}}$ \\
Female & & \\
Age & $20.8^{\mathrm{a}}$ & $80.0^{\mathrm{b}}$ \\
17-21 years & $42.0^{\mathrm{a}}$ & $17.0^{\mathrm{b}}$ \\
22-30 years & $37.2^{\mathrm{a}}$ & $3.0^{\mathrm{b}}$ \\
>30 years & & \\
Marital status & $26.7^{\mathrm{aA}}$ & $2.0^{\mathrm{bA}}$ \\
Married & $67.1^{\mathrm{aB}}$ & $97.0^{\mathrm{bB}}$ \\
Single & $6.2^{\mathrm{aC}}$ & $1.0^{\mathrm{aA}}$ \\
Other & & \\
Religion & $68.4^{\mathrm{aA}}$ & $66.2^{\mathrm{aA}}$ \\
Catholic & $14.6^{\mathrm{aB}}$ & $8.1^{\mathrm{aB}}$ \\
Spiritual & $10.1^{\mathrm{ab}}$ & $11.5^{\mathrm{aB}}$ \\
Evangelist/Protestant & $3.7^{\mathrm{aC}}$ & $9.8^{\mathrm{bB}}$ \\
A gnostic/Atheist & $3.2^{\mathrm{aC}}$ & $4.5^{\mathrm{aC}}$ \\
Other & & \\
\hline
\end{tabular}

upper case letters are significantly different by the chi-square test $(\mathrm{P}<0.05)$. Almost all members of GA and $3 / 4$ of GF have already heard of VBD, but only about $1 / 4$ to $1 / 3$ of each group would participate in one. Most interviewees did not know what legal or other procedures were required for such. Potential donors and non-donors in each group expressed their opinions on why they would or would not donate their bodies. Numbers in the same line followed by different lower case letters or the same column within a question followed by upper case letters are significantly different by the chisquare test $(\mathrm{P}<0.05)$. For the GA donor group, altruism is the main reason for their decision. This is also evident in the GF group, but at a lower level. The $22.9 \%$ of professionals who would donate their body because they are alone is notable. In the non-donor group, religion was not an important factor in their decision-making, but family and the desire to put their body to rest were In the logistic regression no effect was significant to determine whether students would donate their bodies or not, but there was a tendency $(\mathrm{P}<0.10)$ that females and students without other profession declared would be more willing to donate. Those freshmen that had a desire to donate tended to be younger and single while those that did not wish to donate were older and already had another profession. The reasons for donating were varied but seen as a need to contribute to education of future generations.

\section{DISCUSSION}

Although many universities have abandoned the use of cadavers in teaching anatomy (McLachlan et al., 2004; Rizzolo \& Stewart, 2006), dissection and prospection (Winkelmann, 2007) are still important in understanding the three dimensional aspects of anatomy and its variations (Groscurth et al., 2001; Bolware et al., 2004; Sehirli et al., 2004). In recognizing that the sensible use of 3D human body simulators is an important tool in anatomy teaching, Zhang et al. (2008), believe that modern virtual anatomy technologies are precarious in most medical schools. Threfore, the knowledge of anatomy from dissection is fundamental for medical practice and communication, being the basis in the formation of surgeons and doctors (Turney, 2007).

Despite the lack of non-claimed corpses destined for use in anatomy courses, the use of computer resources and synthetic models in the formation of professionals in different areas of the health sciences, worldwide use of dissection continues through the use of bodies donated in well

Table II. Opinions of anatomists (GA) and freshmen (GF) on voluntary body donation (VBD)

\begin{tabular}{|c|c|c|c|}
\hline & Yes & No & No opinion \\
\hline \multicolumn{4}{|c|}{ Have you heard of VBD? } \\
\hline GA & $97.5 \mathrm{aA}$ & $4.3 \mathrm{~b}^{\mathrm{A}}$ & \\
\hline GF & $77.0 \mathrm{a}^{\mathrm{B}}$ & $23.0^{\mathrm{bA}}$ & \\
\hline \multicolumn{4}{|c|}{ Would you participate in a VBD? } \\
\hline GA & $34.2 \mathrm{aA}$ & $30.7^{\mathrm{aA}}$ & $35.1^{\mathrm{aA}}$ \\
\hline GF & $24.9 \mathrm{a}^{\mathrm{B}}$ & $28.4^{\mathrm{aB}}$ & $46.7^{\mathrm{bB}}$ \\
\hline \multicolumn{4}{|c|}{ Do you know which procedures are necessary to participate in a VBD? } \\
\hline GA & $31.4 \mathrm{aA}$ & $68.6^{\mathrm{bA}}$ & \\
\hline GF & $1.3 \mathrm{a}^{\mathrm{B}}$ & $98.7^{\mathrm{bA}}$ & \\
\hline \multicolumn{4}{|c|}{ Have you carried out the legal procedures for a VBD? } \\
\hline GA & $2.4 \mathrm{aA}$ & $97.6^{\mathrm{bA}}$ & \\
\hline GF & $0.3 \mathrm{aA}$ & $99.7^{\mathrm{bA}}$ & \\
\hline
\end{tabular}


Table III. Reasons for VBD donation decision (\%) by anatomists (GA) or freshmen (GF)

\begin{tabular}{lcc}
\hline & \multicolumn{2}{c}{ Donors } \\
\hline & GA & GF \\
To contribute to the advancement of education in area of health & $32.7^{\mathrm{a}}$ & $39.2^{\mathrm{a}}$ \\
To help those studying the subject become a better professional & $19.8^{\mathrm{a}}$ & $17.2^{\mathrm{a}}$ \\
Because I know of the need for this material in Anatomy laboratories & $31.2^{\mathrm{a}}$ & $16.3^{\mathrm{a}}$ \\
I am against burying/cremation or others & $2.0^{\mathrm{a}}$ & $1.4^{\mathrm{b}}$ \\
I will be useful after my death & $8.3^{\mathrm{a}}$ & $14.7^{\mathrm{b}}$ \\
I am alone and have no relatives & $1.0^{\mathrm{a}}$ & $0.0^{\mathrm{b}}$ \\
As thanks to science & $4.0^{\mathrm{a}}$ & $8.4^{\mathrm{b}}$ \\
Others & $1^{\mathrm{a}}$ & $2.8^{\mathrm{b}}$ \\
& $\mathrm{Non}^{\mathrm{a}}-\mathrm{d}$ onors \\
Family would not accept it & $22.4^{\mathrm{a}}$ & $23.8^{\mathrm{a}}$ \\
Science is not prepared to receive cadavers & $13.7^{\mathrm{a}}$ & $3.2^{\mathrm{b}}$ \\
Shame in being recognised & $5.9^{\mathrm{a}}$ & $7.5^{\mathrm{a}}$ \\
I want to be buried/cremated or others & $21.9^{\mathrm{a}}$ & $33.5^{\mathrm{b}}$ \\
Religious reasons & $5.7^{\mathrm{a}}$ & $5.9^{\mathrm{a}}$ \\
Lack of knowledge on techniques used & $1.4^{\mathrm{a}}$ & $11.3^{\mathrm{b}}$ \\
Others & $10.4^{\mathrm{a}}$ & $7.6^{\mathrm{a}}$ \\
\hline
\end{tabular}

established programs (Dluzen et al., 1996; Watkins et al., 1998; Cahill \& Ettarh, 2008; Rocha et al., 2012).

Based on altruistic donation programs, universities find their main source of cadavers in general society. These bodies, obtained through programs which have improved their rules over time, have not been sufficient to substitute the use of non-claimed corpses for dissection (Baumel, 1968; Hamel, 1975; Bullen \& Crase, 1998; Chung \& Lehmann, 2002; Boulware et al., 2004). Nevertheless, widespread publicising of the program (for example the Uniform Anatomical Gift ACT in Virginia University as described by Wiecking, 1974) can lead to a significant increase in donations. Other institutions have also seen their cadaver number rise after institutionalization of the donation program, such as Cornwall \& Stringer (2009) in the University of Otago, New Zealand which began in 1943 and receives over 40 bodies per year and Rocha et al. (2012), who implanted a program in 2008 in the Federal University of Health Sciences in Porto Alegre, Brazil and saw their numbers increase from 26 to 147 bodies.

Admitting the important role of dissection, there is a reluctance in accepting consent as this involves a number of important factors which need to be re-evaluated (McDonald, 2009). The data collected here can be studied together with similar questions raised by other institutions.

According to Winkelmann \& Güldner (2004), religion was an important obstacle for the donation program in Thailand, where Buddhism is prevalent and approval for donation comes from the king. Zhang et al. (2008), found that, in China, due to difficulties due to religious beliefs, it was necessary to create an "Educational center for medical ethics" to improve information and teaching of eventual donors. In the present study, religion was not an important barrier to donation (5.7 and $5.9 \%$ in GA and GF, respectively).

Family acceptance, on the other hand, was important (22.4 and $23.8 \%$ in GA and GF, respectively), similar to results found by Sehirli et al. (2004), in the University of Marmara, Turkey, who found $26.5 \%$. In that country, parents and relatives stated that psychological factors (43.4\%) was the most important reason for not donating, while in the present study cultural factors such as the need to bury or cremate the body was cited (21.9 and $33.5 \%$ in GA and GF, respectively).

The desire to be useful after death was the main reason for donation cited by Bolt et al. (2010) in the University of Groningen, the Netherlands while here the replies were 22.9 and $23.5 \%$ in GA and GF, respectively.

In a study in University College Dublin (Ireland), $83.8 \%$ of first year medical students accepted the donation of bodies by unknown people while $43.2 \%$ of family members.Cahill \& Ettarh (2008), at the same university, it was found that $31.5 \%$ were favorable for donation at the beginning of the course and only $19.6 \%$ after 9 weeks, meaning that the altruistic motivation may have been discouraged by this procedure. In the present study, the fact that the GF did not have contact with cadavers or dissection or detailed information on the theme, may have influenced the student who did not have a formed opinion (46.7\%) and led to the relatively high percentage of non-donors. 
Comparing the results here with other studies, it is possible to discern that help (meaning to aid, support, rescue) and gratefulness (recognition or acknowledgment) are important in most studies. Fennel \& Jones (1992) in Otago Medical School (New Zealand), found that most donors wanted to help or were grateful to science. In the same school but with a different approach, McClea \& Stringer (2010) concluded that the main reason was to help education and science. In the present study these were also important factors with $19.8 \%$ of anatomists and $17.2 \%$ of freshman wanting to help professional formation, thank science $(13.3 \%$ of GA and $11 \%$ GF) and contribute to advancements in education in health sciences $(32.7 \% \mathrm{GA}$ and $39.2 \% \mathrm{GF})$. Therefore the main reasons are linked to the desire to effectively contribute to developing and improving science.

Although only 163 of the 1000 GS doctors replied to the study, all recognized the importance of dissection for their formation. In the same manner, 846 representatives of the general public (GP) manifested their confidence in professionals who learned their trade using human cadavers (96.1\%), which reinforces the need to create a VDBAnat/ USP. Important points in creating this program are described below.

It is important that the donor manifests and officializes their desire to donate while alive. This enables, speeds up and reduces bureaucracy in the donation process after death. Nevertheless, the desire to donate can be registered by first-degree relatives although this may cause conflict at the moment of death.

The procedures for Voluntary Body Donation should be known by the funeral service (in this case of the Municipality of São Paulo), as, when questioned, they knew little on the topic. One point should be noted here. It was felt that the attendants could change their degree of understanding over time, if this procedure was repeated several times. As there is a single attendant in the SFMSP apt to answer doubts, orient and carry out the procedure, there is a need for a normative provision by the General Justice of the State of São Paulo.

The donation process should follow the fluxogram (protocol) described but the emission of a death certificate depends on the following:

a) Time the relatives take to request he death certificate from the nearest register.

b) Understanding of the person responsible for emitting the death certificate which can be immediate or depend on the time to create a process to be sent to the Judge responsible for the public register.

c) Appreciation by the Judge, who requires a period of at least 15 days for possible challenges.

d) Drafting the death certificate.

e) Delivery of death certificate to VDBAnat/USP.

The following example, which occurred in 2012, shows the difficulties found in the present process, which delayed the emission of the death certificate. At first, the register gave a 5 day period to deliver the death certificate to family members. After this period, the procedure was altered, as it was stated the university should request the certificate (as with non-claimed corpses). The family informed the registry that it was a donation and not an indigent and so it was the responsibility of the family and not the university. They explained that the registry should build a process to send to the judge, which delayed the process 45 days to obtain the death certificate. Only then could the family inform the pension office and insurance company and receive the policies that were due. This caused problems for the family who had bills to pay.

Body donation should be an option for altruistic people but should not cause problems for their family, especially in times of loss and pain. Therefore, adequate information from the funeral service and speed in drafting the death certificate are vital steps in the process. The authors held a meeting with the Public register Judge in São Paulo who stated that to carry out the necessary changes the state internal affairs office should issue a provision. This is awaiting approval at present.

The main task after implantation of the VDBAnat/ USP is ample dissemination of the process so that palliatives such as that used by the University of Servia are not necessary (Stimec et al., 2010). In this case, the use of non-claimed indigents is seen as a provisional solution until the general public reaches a sufficient level of conscience to donate sufficient bodies. That country offers little information to its citizens and does not have adequate legislation.

Although a long time has passed since the creation of the Boverian School of Anatomy, it is hoped that the present study helps in increasing the number of bodies donated and maintaining the subject alive in USP (Talamoni, 2012):

"in contemplating the linearity through which the teaching of anatomy is praticed, it is not suggested that the boverian method of teaching is superfluous; it continues to be fundamental for dissection which, despite new technologies, continues to be a fundamental teaching resource for anatomy students 
SIMÃO, T. R. P.; MIGLINO, M. A.; DA SILVA, J. B.; McMANUS, C. \& LIBERTI E. A. Implementación de un programa de donación voluntaria de cuerpos para estudio anatómico en la Universidad de São Paulo, Brasil. Int J. Morphol., 34(4):1494-1501, 2016.

RESUMEN: Los cadáveres no reclamados fueron durante muchos años la fuente de material humano para el estudio de la anatomía humana. Sin embargo, debido a la mejora de la calidad de vida y la tecnología, ha habido una disminución de éstos. Frente a estas circunstancias, y la imposibilidad de la total sustitución de este material por otros en la formación de futuros profesionales y de la técnica de la disección, la donación voluntaria de cuerpos para el estudio anatómico se presenta como una alternativa a los cadáveres no reclamados o quienes desean donar su cuerpo o parte de este a instituciones de investigación y estudio científico, sin obtener ningún beneficio pecuniario. Así, el presente estudio tuvo como objetivo reunir información sobre el conocimiento y la creencia que tiene los anatomistas y estudiantes de primer año, sobre el tema; De esta manera se pretende obtener información sobre la importancia de la disciplina y la disección para la práctica profesional y la confiabilidad de la población en general, y desarrollar el Programa de Donación Voluntaria de Cuerpos para Estudio Anatómico (pdvcea) para la Universidad de São Paulo (DA-ICB / USP). Respecto a la importancia de la disección para la formación profesional se considera, para la población en general, como el factor de fiabilidad en el profesional médico cirujano, la posibilidad de donar órganos no es desconocida para la mayoría de la población estudiada, que no necesariamente se establece en donantes potenciales. El pdvcea fue creado e institucionalizado, pero todavía está en proceso de adquirir recursos para la institución; dependiente para su difusión, aclaración y colocación en los medios de comunicación, para disminuir el tiempo de redacción de la causa de muerte, sin pérdida económica para los familiares de los donantes.

PALABRAS CLAVE: Donación. Cadáveres Disección. Anatomía.

\section{REFERENCES}

Baumel, J. J. Donation of bodies for medical education. Nebr. State Med. J., 53(3): 90-2, 1968.

Bolt, S.; Venbrux, E.; Eisinga, R.; Kuks, J. B. M.; Veening, J. G.; Gerrits, P. O. Motivation for body donation to science: More than an altruistic act. Ann. Anat., 192(2):170-4, 2010.

Boulware, L. E.; Ratner, L. E.; Cooper, L. A.; LaVeist, T. A. \& Powe, N. R. Whole body donation for medical science: a population-based study. Clin. Anat., 17(7):570-7, 2014.

Bullen, D. \& Crase, D. The ultimate gift: body donation. Omega (Westport), 37(1):75-83, 1998.

Cahill, K. C. \& Ettarh, R. R. Student attitudes to whole body donation are influenced by dissection. Anat. Sci. Educ., 1(5):212-6, 2008.
Carvalho, I. S.; Costa Júnior, P. B.; Araújo, R. M. \& Araújo, R.D.T. Alternativa para o estudo da anatomia humana no ensino superior. In: REUNIÃO ANUAL DA SOCIEDADE BRASILEIRA PARA O PROGRESSO DA CIÊNCIA, 64., 2010. Available in: <http://www.sbpcnet.org.br/livro/62ra/ resumos/resumos/1745.htm>. Access: January 12, 2013.

Cornwall, J. \& Stringer, M. D. The wider importance of cadavers: Education and research diversity from a body bequest program. Anat. Sci. Educ., 2(5):234-7, 2009.

Chung, C. S. \&Lehmann, L. S. Informed consent and the process of cadaver donation. Arch. Pathol. Lab. Med., 126(8):964-8, 2002.

Conselho Regional de Medicina. Disponível em http:// www.cremesp.com.br Acesso em novembro de 2010.

De Caro, R.; Macchi, V. \& Porzionato, A. Promotion of Body Donation and Use of Cadavers in Anatomical Education at the University of Padova. Anat. Sci. Educ., 2(2):91- 2, 2009.

Dluzen, D. E.; Brammer, J. C.; Bernard, J. C.; \&Keyser, M. L. Survey of cadaveric donors to a body donation program: 19781993. Clin. Anat., 9(3):183-92, 1996.

Fennell, S. \& Jones, D. G. The bequest of human bodies for dissection: a case study in the Otago Medical School. New Zealand Med. J., 105(946):472-4, 1992.

Groscurth, P.; Eggli, P.; Kapfhammer, J.; Rager, G.; Hornung, J. P. \& Fasel, J. D. Gross Anatomy in the Surgical Curriculum in Switzerland: Improved Cadaver Preservation, Anatomical Models, and Course Development. Anat. Rec. (New Anat.), 265(6): 254-6, 2001.

Gunderman, R. B. Giving Ourselves: The ethics of anatomical donation. Anat. Sci. Educ., 1(5):217-9, 2008.

Hamel, E.G. Jr. Editorial: the gift of life. Anatomical donations and the teaching of anatomy. Ala. J. Med. Sci., 12(2):188-9, 1975.

McClea, K. \& Stringer, M. D. The profile of body donors at the Otago School of Medical Sciences- has it changed? The New Zealand Med. J.,123(1312):9-17, 2010.

McLachlan, J. C.; Bligh, J.; Bradley, P. \& Searle, J. Teaching anatomy without cadavers. Med. Educ., 38(4):418-24, 2004.

McDonald, H. The anatomy inspectorate and the government corpse. History Australia, 6(2):1-17, 2009.

Pasqualucci, C. A. Eles querem seu corpo. Available in: ,http;// revistaepoca.globo.com/revista/epoca/0,,EMI5715115257,00.html. Access: September 27, 2012.

Rizzollo, L. \& Stewart, W. B. Should we continue teaching anatomy by dissection when? Anat. Rec., 289B:215-8, 2006. 
SIMÃo, T. R. P.; MIGLINO, M. A.; DA SILVA, J. B.; McMANUS, C. \& LIBERTI E. A. Implementation of a program of voluntary body donation for anatomical study in the University of São Paulo, Brazil. Int J. Morphol., 34(4):1494-1501, 2016.

Rocha, A.O.; Tormes, D.A.; Lehmann, N.; Schwab, R.T.C. The body donation program at the federal university of health sciences of Porto Alegre: a successful experience in Brazil. Anat. Sci. Educ., 5(6):1-6, 2012.

Sehirli, U. S.; Saka, E. \& Saikaya, O. Attitudes of Turkish anatomists toward cadaver donation. Clin. Anat., 17(8):67781,2004

Stimec, V. B.; Draskic, M. \& Fasel, J. H. D. Cadaver procurement for anatomy teaching: legislative challenges in a transitionrelated environment. Med. Sci. Law, 50(1):45-9, 2010.

Survey Monkey. Disponível em: http://www.surveymonkey.com Acesso em: novembro de 2010.

Talamoni, A. C. B. O Laboratório de Anatomia sob a perspectiva da 'descrição densa'. Interfaces da cultura científica e o Ensino de Ciências. 2012. 377 papers. Tese (Ph.D. in Education Science) - Universidade Estadual Paulista "Júlio de Mesquita Filho”, Faculty of Sciences, São Paulo, 2012.

Turney, B. W. Anatomy in a modern medical curriculum. Ann. Royal Coll. Surg. Engl., 89(2):104-7, 2007.

UFMG. Universidade Federal de Minas Gerais. Available in: <http:/ /www.medicina.ufmg.br/vidaaposvida/>. Access: November 10,2010

Watkins, B. P.; Haushalter, R. E.; Bolender, D. L.; Kaplan, S. \& Kolesari, G. L. Postmortem Blood Tests for HIV, HBV, and HCV in a Body Donation Program. Clin. Anat., 11(4):250-2, 1998.

Wiecking, D. K. Donation of the body for scientific study. Virginia Med. Month., 101(5): 393-4, 1974.

Winkelmann, A. \& Güldner, F. H. Cadaver as teachers: the dissecting room experience in Thailand. BMJ, 329(7489):14557, 2004.

Zar, J. H. Biostatistical analysis. $2^{\text {nd. }}$ ed. New Jersey, Prentice-Hall, 1984. pp. 191-5.

Zhang, L.; Wang, Y.; Xiao, M.; Han, Q. \& Ding, J. An ethical solution to the challenges in teaching anatomy with dissection in the chinese culture. Anat. Sci. Educ., 1(2):56-9, 2008.
Correspondence to:

Maria Angélica Miglino

Department of Surgery

Faculty of Veterinary Medicine

University of São Paulo

Avenida Professor Orlando Marques de Paiva, 87

CEP 13635900.

BRAZIL

Email: miglino@usp.br

Received: 18.06.2106

Accepted: 